\title{
SALURAN, MARGIN DAN EFISIENSI PEMASARAN RUMPUT LAUT DI SENTRA KAWASAN MINAPOLITAN KABUPATEN SUMBAWA
}

\author{
Seaweed Marketing Channels, Margin and Efficiency \\ in The Minapolitan Area of Sumbawa District
}

\author{
*Hikmah' dan Agus Heri Purnomo² \\ ${ }^{1}$ Balai Besar Riset Sosial Ekonomi Kelautan dan Perikanan \\ Gedung BRSDMKP KP I Lt. 4 \\ Jalan Pasir Putih Nomor 1 Ancol Timur, Jakarta Utara \\ Telp: (021) 64711583 Fax: 64700924 \\ ${ }^{2}$ Balai Besar Riset Pengolahan Produk dan Bioteknologi Kelautan dan Perikanan \\ JL. KS Tubun, Petamburan VI, Slipi, Jakarta Pusat \\ *email: hikmah_madani@yahoo.com \\ Diterima tanggal: 10 Juli 2017 Diterima setelah perbaikan: 9 November 2017 \\ Disetujui terbit: 17 Desember 2017
}

\begin{abstract}
ABSTRAK
Komoditas rumput laut merupakan salah satu komoditas yang mampu meningkatkan ekonomi masyarakat, menyerap tenaga kerja dan meningkatkan devisa, namun mengalami permasalahan pada aspek pemasaran terutama menyangkut lembaga, saluran, dan jaringan serta pola pemasaran. Penelitian ini bertujuan untuk mengetahui pola saluran, margin dan efisiensi pemasaran yang diperoleh masing-masing lembaga. Data dikumpulkan dengan observasi dan wawancara, di mana populasi dalam penelitian ini adalah pembudiaya rumput laut, pengumpul rumput laut, eksportir dan industri pengolahan rumput laut di daerah Kabupaten Sumbawa. Pemilihan sampel (responden) pembudidaya rumput laut digunakan metode purposive sampling, sedangkan sampel pedagang digunakan metode snowball sampling. Analisis data menggunakan pendekatan deskriptif kuantitatif berdasarkan analisis biaya dan margin pemasaran serta perhitungan pangsa (farmer's share). Hasil penelitian menunjukkan bahwa pola saluran pemasaran rumput laut di sentra kawasan minapolitan Kabupaten Sumbawa terbagi menjadi tiga, dimana saluran pemasaran saluran 1 lebih panjang dibanding saluran pemasaran 2 dan 3 . Saluran yang paling efisien terjadi pada saluran pemasaran 2 dimulai dari pembudidaya dijual ke pengumpul lokal 2 diteruskan pedangang besar di Lombok kemudian ke eksportir Surabaya dan berakhir di pabrik mancanegara. Pada saluran ini merupakan saluran yang relatif lebih pendek dan margin yang kecil $13,3 \%$ atau Rp. 1000,- (per kilogram) serta nilai farmer's share (86,67 \%) yang paling besar dibanding saluran 1 dan 2. Untuk itu, perlu dukungan kebijakan untuk menguatkan saluran pemasaran 2 dengan meningkatkan keberpihakan terhadap pembudidaya rumput laut yang tercermin dari besaran farmer's shere.
\end{abstract}

Kata Kunci: saluran pemasaran; margin; efisiensi rumput laut

\begin{abstract}
Seaweed is a commodity that could improve the community economic, absorb labor and increase foreign exchange. However, problems occur in marketing particularly related to institutions, channels, networks and marketing patterns. This study aims to determine the channel patterns, margins and marketing efficiency obtained by each institution. Data was collected by observations and interviews toward seaweed growers, seaweed collectors, exporters and seaweed processing industries in the Sumbawa Regency. Samples (respondents) of seaweed cultivators were selected using purposive sampling method, while the merchant samples were selected using snowball sampling method. Quantitative descriptive approach was used to analyzed the data based on analysis of marketing costs and margins as well as share calculations (farmer's share). The study suggests that the seaweed marketing channel pattern in minapolitan area of Sumbawa Regency was divided into three, where marketing channel 1 were longer than marketing channel 2 and 3. The most efficient channel occurred in marketing channel 2 starting from farmers to local collectors 2, forwarded to wholesellers in Lombok, then to Surabaya exporters and ended up in foreign factories. This is a relatively shorter channel with small margin of $13.3 \%$ or Rp. 1000, - (per kilogram) and has the highest value of farmer's share (86.67\%) compared to channel 1 and 2. Therefore, policy is necessary to strengthen marketing channel 2 by supporting seaweed farmers as reflected in farmer's share percentages.
\end{abstract}

Keywords: marketing channels; margin; seaweed efficiency 


\section{PENDAHULUAN}

Komoditas rumput laut merupakan salah satu komoditas yang mampu meningkatkan ekonomi masyarakat, menyerap tenaga kerja dan meningkatkan devisa negara. Pemanfaatan rumput laut dewasa ini semakin luas dan beragam, karena peningkatan pengetahuan akan komoditas ini. Umumnya rumput laut banyak digunakan sebagai bahan makanan bagi manusia, sebagai bahan obat-obatan (anticoagulant, antibiotics, antimehmetes, antihypertensive agent, pengurang kolesterol, dilatory agent, dan insektisida). Rumput laut juga banyak digunakan sebagai bahan pakan organisme di laut, sebagai pupuk tanaman dan penyubur tanah, sebagai pengemas transportasi yang sangat baik untuk lobster dan clam hidup (khususnya dari jenis Ascophyllum dan focus), sebagai stabilizer larutan, dan juga kegunaan lainnya. Perkembangan produk turunan dewasa ini juga sudah banyak diolah menjadi kertas, cat, bahan kosmetik, bahan laboratorium, pasta gigi, es krim, dan lain-lain (Indriani dan Suminarsih, 1999).

Perkembangan produksi rumput laut pada tahun 2010 mencapai 3.915.016 ton dan naik rata-rata $34,21 \%$ dari tahun 2005 , kenaikan tertinggi dibanding dengan komoditas lainnya. Daritotal produksinasional, Kabupaten Sumbawa merupakan produsen rumput laut terbesar yang kedua di Indonesia. Produksi rumput laut di Kabupaten Sumbawa terus meningkat dari tahun 2007 yakni sebesar 75.509 ton menjadi 162.411 ton dengan kenaikan rata-rata $31,80 \%$ (DJP2HP, 2012).

Permasalahan pada pengembangan rumput laut sering terjadi pada aspek pemasaran yaitu aspek kelembagaan, jaringan pemasaran, dan kesenjangan komonikasi antara produsen dan penggunanya. Panjangnya rantai pemasaran rumput laut menyebabkan margin yang diterima pembudidaya relatif masih kecil (Hikmayani, et.al., 2005). Pemasaran rumput laut yang cukup panjang mempengaruhi efesiensi pemasaran (Anggadireja, 2008). Oleh karena itu, makalah ini bertujuan mengetahui tentang saluran pemasaran rumput laut, biaya, keuntungan, margin pemasaran dan efisiensinya.
Penelitian menggunakan metode survey di Kabupaten Sumbawa pada bulan Maret 2012. Data primer yang dihasilkan untuk memenuhi kebutuhan penyelidikan yang sedang ditangani (Maholtra, 1996), diperoleh melalui observasi langsung di lapangan dan wawancara dengan beberapa pelaku usaha yang ditentukan secara purposive sampling (Singarimbun dan Effendi, 1995) dan snowball sampling (Juanda, 2009). Data sekunder berupa buku, dokumen, data, laporan, artikel, jurnal yang terkait dengan usaha budidaya rumput laut, perdagangan rumput laut, perkembangan harga rumput laut serta industri pengolahan rumput laut yang diperoleh melalui instansi dan lembaga terkait serta melalui kajian pustaka. Selanjutnya dilakukan analisis biaya dan margin pemasaran (cost margin analysis) (Tomek and Robinson, 1990) dan analisis efisiensi pemasaran (Pursell, 1979).

\section{KARAKTERISTIK LEMBAGA PEMASARAN}

Pemasaran adalah semua keragaan dari kegiatan bisnis yang termasuk dalam penyaluran produk dan jasa mulai dari titik nol sampai ke tangan konsumen (Kohl dan Uhl, 1990). Lembaga pemasaran berfungsi pemasaran untuk memperlancar proses perpindahan barang dan/ atau jasa. Fungsi pemasaran yang dilakukan perorangan atau kelompok pada dasarnya terbagai menjadi tiga, yaitu: fungsi pertukaran, fungsi fisik, dan fungsi fasilitas. Fungsi lembaga yang terlibat dalam pemasaran rumput laut berbeda-beda. Lembaga pemasaran yang terlibat dalam saluran pemasaran di kawasan sentra minapolitan adalah: pembudidaya rumput laut, pedagang lokal (pengumpul lokal 1 dan 2 ), pedagang pengumpul besar (pengumpul Kabupaten dan pedagang cabang eksportir) dan pengolah Kabupaten Sumbawa.

\section{Pembudidaya Rumput Laut}

Pembudidaya sebagai produsen rumput laut di Sumbawa. Mayoritas pembudidaya di Sumbawa juga bertindak sebagai pembibitan, sehingga mereka tidak perlu untuk memasok bibit dari luar karena mereka sering cukup memilah benih dari budidaya sendiri untuk diregenerasi kembali ke dalam benih berikutnya, dan atau dijual kembali dalam bentuk basah. 


\section{Pedagang}

\section{a. Pedagang Pengumpul Lokal (di Tingkat Desa)}

Pedagang pengumpul lokal rumput laut terdiri dua jenis yaitu:

- Pedagang Pengumpul Lokal 1: umumnya masih berskala usaha kecil yang berperan menampung panen dari para pembudidaya di tingkat desa. Pedagang pengumpul lokal 1 sebagian besar berperan sebagai perantara. Hampir semua pedagang pengumpul lokal I juga merupakan pembudidaya rumput laut. Pedagang pengumpul lokal I melakukan pembelian secara langsung kepada pembudidaya rumput laut dan transaksi dilakukan secara langsung di rumah pembudidaya. Pedagang pengumpul desa bertugas mencari rumput laut kering dari pembudidaya, kemudian melakukan pembelian dan pembayaran. Selanjutnya para pedagang ini menyetorkan rumput laut kering ke pedagang besar cabang eksportir yang ada di Kabupaten Sumbawa. Penyetoran dilakukan seminggu sekali dengan kapasitas rata-rata $700-750 \mathrm{~kg}$ per minggu, namun apabila musim sedang bagus kapasitas setor bisa mencapai 3 ton per 1 orang pedagang pengepul lokal 1.

Pedagang pengumpul lokal 1 tidak mengeluarkan biaya karena semuanya ditanggung pedagang pengumpul besar. Fungsi pedagang pengumpul lokal I adalah:

(1) fungsi pertukaran berupa pembelian dan penjualan; (2) fungsi fisik berupa pengangkutan; dan (3) fungsi fasilitas berupa penanggungan resiko, yaitu tersendatnya pembayaran dari pedagang pengumpul besar. Proses pembayaran dilakukan dirumah pembudidaya secara tunai atau tempo dengan jangka waktu satu sampai beberapa hari, tergantung kepercayaan pembudidaya dan keuangan pedagang.

\section{- Pedagang Pengumpul Lokal 2;}

Hampir sama dengan pedagang pengumpul lokal 1, fungsi dan peranan pedangan pengumpul lokal 2 adalah menampung panen rumput laut dari pembudidaya.
Bedanya adalah modal untuk pembelian menggunakan modal sendiri, bukan dari pedagang besar. Pembudidaya rumput laut yang biasa menjadi langganan pedagang pengumpul 2 merupakan kelompokkelompok pembudidaya binaan dinas kelautan dan perikanan setempat. Namun terkadang juga menampung dari pengumpul lokal 1 yang ada di Kabupaten Sumbawa. Terdapat sekitar 5 kelompok pembudidaya tetap yang selalu menyetrokan hasil panennya ke pedagang pengumpul lokal 2 ini. Selanjutnya disalurkan ke pedagang besar di Lombok dengan volume penjualan hingga 18 ton per bulan.

\section{b. Pedagang Pengumpul Besar}

\section{- Pedagang Pengumpul Besar Antar Provinsi}

Kabupaten Sumbawa terdapat dua pedagang besar yaitu pedagang antar provinsi. Pedagang pengumpul besar yang bertindak sebagai gudang pengumpul hasil budidaya rumput laut yang dibeli dari para pengumpul lokal di wilayah Sumbawa untuk kemudian dilakukan proses penjemuran, penyortiran, penimbangan, dan packaging yang kemudian di kirim ke eksportir yang berada di Surabaya.

\section{- Pedagang Besar Cabang Ekportir} (Perusahaan)

Pedagang besar cabang eksportir berfungsi sebagai penampung skla besar dari pengumpul-pengumpul kecil. Pedagang pengumpul besar cabang eksportir menanggung resiko penyusutan maupun kerusakan barang saat penyortiran maupun selama perjalanan. Selain resiko penyusutan, resiko yang ditanggung adalah tidak dibayarnya barang dagangan oleh pembeli. Fungsi pemasaran yang dilakukan oleh pedagang pengumpul besar adalah: (1) Fungsi pertukaran berupa pembelian dan penjualan; (2) Fungsi fisik berupa pengangkutan dan penyimpanan; dan (3) Fungsi fasilitas berupa penyortiran dan grading, sumber informasi pasar, sumber pembiayaan, dan penanggungan resiko. 
Pembayaran oleh pedagang pengumpul lokal 1 dan 2 kepada pembudidaya dilakukan secara tunai. Selanjutnya pembayaran dari pedagang besar kabupaten dan cabang eksportir kepada pedagang pengumpul lokal 1 dan 2 dilakukan secara tempo hingga beberapa hari tergantung kesepakatan dan tingkat kepercayaan. Terdapat sekitar 15 pengumpul tetap yang menyetorkan rumput laut ke pedagang besar cabang ekportir yang ada di Kabupaten Sumbawa.

Struktur dalam perusahaan cabang eksportir terdiri dari kepala gudang, supir, dan penjaga keamanan yang dibayar dengan sistem gaji bulanan, sementara tenaga kerja bongkar muat, tenaga kerja penjemuran, serta tenaga kerja processing dan pengepakan yang dibayar berdasarkan upah pengerjaan per karung rumput laut yang seluruhnya di bayar oleh perusahaan eksportir pusat di Surabaya.

Frekuensi pengiriman rumput laut laut kering ke Surabaya dalam 1 bulan rata-rata sekitar 4-6 kali, dengan rata-rata volume pengiriman per minggu sekitar 18 Ton. Sistem pembelian rumput laut yaitu dengan membeli langsung dari pembudidaya dengan harga Rp.7500/kg melalui perantara pengumpul (pengumpul lokal 1) yang mendapat upah sekitar Rp.500/kg.

Dalam menjalankan fungsi-fungi pemasaran, masih terdapat permasalahanpermasalahan pemasaran yang dapat mengurangi nilai produk yang dipasarkan. Sebagai contoh rumput laut yang diperjualbelikan adalah rumput laut yang tingkat kekeringannya dibawah standar minimal $70 \%$ (kering karet). Rumput laut kering diperjual belikan dalam satu kelompok tanpa pembedaan kelas-kelas tertentu (grading). Tidak ada standar yang baku tentang kualitas komoditi yang diperjualbelikan, misalnya rumput lautyang proses penjemurannya dilakukan menggunakan para-para terjamin kebersihannya dengan yang rumput laut yang dijemur di atas pasir harganya tetap sama.

Kondisi ini sering menjadi permasalahan pemasaran yang umum terjadi dinegara-negara berkembang. Seperti yang dinyatakan oleh Harrison (1988), masalah-masalah pemasaran di sektor pertanian termasuk perikanan antara lain; banyaknya pedagang perantara yang terlibat, tingginya susut, praktek spekulasi dan mopsoni oleh perantara, pinjaman perantara yang mengarah pada harga yang tidak wajar terhadap hasil yang diterima pembudidaya, tidak cukupnya informasi pasar dan tidak adanya standarisasi dan grading.

\section{POLA SALURAN PEMASARAN}

Pola saluran pemasaran rumput laut di Kabupaten Sumbawa terdiri dari tiga saluran. Dari ketiga saluran tersebut, dua saluran bermuara ke perusahaan eksportir di luar daerah untuk dipasarkan kembali ke pasar internasional, yakni Hongkong, Cina dan satu

Tabel 1. Fungsi-Fungsi Lembaga Pemasaran Rumput Laut Kering dari Sentra Kawasan Minapolitan, Kabupaten Sumbawa, 2012.

\begin{tabular}{|c|c|c|c|c|c|}
\hline \multirow[b]{2}{*}{ Fungsi-fungsi } & \multirow[b]{2}{*}{ Pembudidaya } & \multicolumn{3}{|c|}{ Pedagang } & \multirow[b]{2}{*}{ Pengolah } \\
\hline & & $\begin{array}{l}\text { Pengumpul } \\
\text { lokal } 1\end{array}$ & $\begin{array}{l}\text { Pengumpul } \\
\text { lokal } 2\end{array}$ & $\begin{array}{c}\text { Pengumpul } \\
\text { Besar }\end{array}$ & \\
\hline \multicolumn{6}{|l|}{ Pertukaran } \\
\hline - Pembelian & Tidak & Ya & Ya & Ya & Ya \\
\hline - Penjualan & Ya & $\mathrm{Ya}$ & Ya & Ya & Ya \\
\hline - Penyimpanan & Tidak & Tidak & Ya & Ya & Ya \\
\hline - Pengangkutan & Ya & Ya & Ya & Ya & Ya \\
\hline - Pengolahan & Tidak & Tidak & Tidak & Tidak & Ya \\
\hline \multicolumn{6}{|l|}{ Fasilitas } \\
\hline - Penyortiran & Ya & Tidak & Ya & Ya & Ya \\
\hline - Penaggungan resiko & Ya & Ya & Ya & Ya & Ya \\
\hline - Informasi pasar & Ya & Tidak & Ya & Ya & Ya \\
\hline - Pembiayaan & Ya & Tidak & Ya & Ya & Ya \\
\hline
\end{tabular}


saluran bermuara ke industri makanan olahan di pasar lokal (Sumbawa) dan luar daerah (Mataram dan Surabaya). Ketiga saluran tersebut adalah sebagai berikut:

\section{Pola Saluran 1}

Sistem pemasaran ini cukup banyak dilakukan oleh pembudidaya di Kabupaten Sumbawa. Dalam perdagangan rumput laut kering dari pembudidaya ke pengumpul lokal I sampai ke pedagang besar cabang eksportir ini pembudidaya menjual rumput laut kering kepada pengumpul lokal I di lokasi budidaya atau di lokasi pengumpul tanpa melakukan klasifikasi. Saluran nilai rumput laut kering dari pembudidaya ke pengumpul lokal I dapat dilihat pada Gambar 1.

Saluran ini menghasilkan laba/ pertambahan nilai sebesar Rp. 3.526,- per $\mathrm{kg}$ rumput laut kering dengan biaya untuk menghasilkan pertambahan nilai sebesar Rp. 5.715.-per kg. Dari jumlah laba/pertambahan nilai, pembudidaya menerima bagian terbesar, yaitu $74 \%$, dan menghabiskan bagian terbesar di sisi biaya $(76,8 \%)$. Pembudidaya rumput laut menghabiskan sebagian besar dari biaya tersebut untuk biaya penyusutan asset (tali ris, tali pengikat, tali jangkar, tali induk, jangkar induk, jangkar samping, pelampung botol, pelampung sudut, perahu, mesin, para-para), biaya operasional (Bibit rumput laut dan BBM), tenaga kerja (pengikat bibit, pemeliharaan, panen, dan pengikat tali ris), dan biaya lainnya yang dibutuhkan untuk menghasilkan produk. Pembiayaan paling besar yang dikeluarkan oleh pembudidaya rumput laut ini adalah untuk biaya operasional, yakni rata-rata sebesar $49,4 \%$ dari total biaya.

Pada saluran pemasaran pedagang pengumpul I kemudian ke perusahaan pengumpul besar cabang eksportir biaya yang dikeluarkan untuk menghasilkan pertambahan nilai hanya sedikit. Oleh karena itu, pertambahan nilai yang dihasilkan adalah kecil. Lebih lanjut, terlihat bahwa pengumpul lokal mengeluarkan biaya paling kecil yaitu sebesar $7,6 \%$ sedangkan laba/pertambahan nilai yang dihasilkan oleh pengumpul kecil justru lebih besar $(16 \%)$ dibanding dengan pertambahan nilai yang dihasilkan oleh pengumpul besar cabang eksportir yang hanya mendapat sebesar $10 \%$, padahal biaya yang dikeluarkan lebih besar dari pengumpul lokal (15,6\%). Hal ini dikarenakan perusahaan cabang eksportir lebih mengedepankan kuantitas volume penjualan, sehingga walaupun untung per kilogram yang diterima sedikit namun dengan volume besar maka keuntungan yang didapat juga semakin besar. Di sisi lain, perusahaan cabang eksportir ini juga hanya merupakan anak buah dari perusahaan eksportir besar di luar daerah, yakni Surabaya, yang menggunakan sistem gaji terhadap para tenaga kerjanya.

Saluran pemasaran rumput laut dari Kabupaten Sumbawa ini kemudian berlanjut ke luar daerah, dimana pengumpul besar cabang eksportir kemudian menyetorkan penjualannya ke perusahaan eksportir pusat di Surabaya.

1. Biaya Tetap $(11,7 \%)$

2. Biaya Operasional $(49,4 \%)$

3. Biaya Tenaga Kerja (38,9\%)

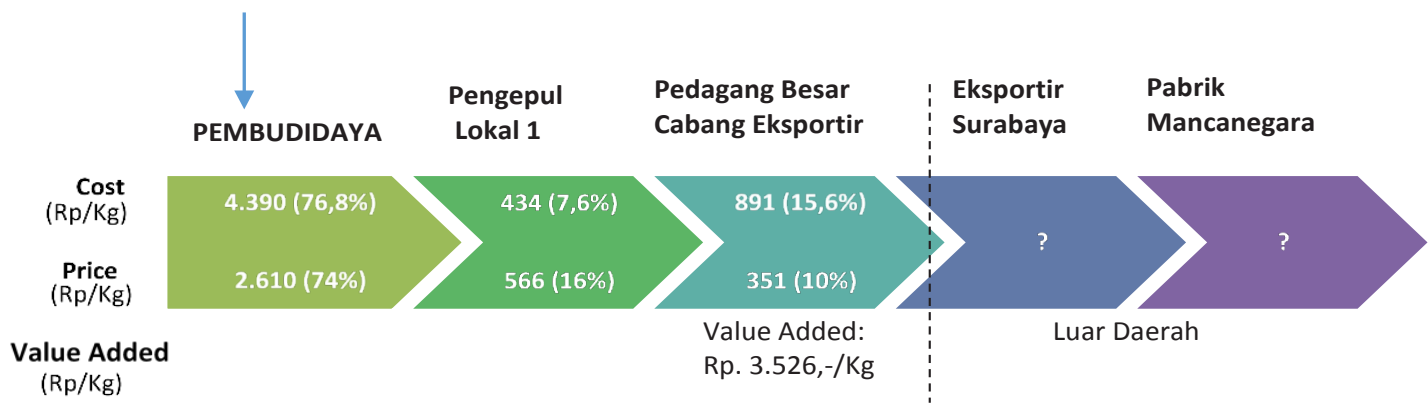

Gambar 1. Pola Saluran Pemasaran Rumput Laut 1 
Dari perusahaan eksportir di Surabaya kemudian diekspor ke pasar mancanegara, biasanya berupa pabrik pemroses yang ada di Hongkong, Cina.

\section{Pola Saluran 2}

Saluran pemasaran melalui pengumpul lokal 2 ini juga bermuara ke eksportir, hanya saja melalui jalur yang berbeda. untuk saluran ini dari Sumbawa rumput laut dikirim dahulu ke pengumpul besar di Lombok untuk kemudian disetorkan lagi ke eksportir pusat di Surabaya. Dari Surabaya kemudian diekspor ke pabrik pemroses mancanegara. Pembudidaya menjual rumput laut kering kepada pengumpul lokal 2 di lokasi pengumpul tanpa melakukan klasifikasi. Pengumpul 2 ini kemudian membuatkesepakatan harga dengan pedagang besar di luar daerah, yakni pedagang besar di daerah Lombok. Alasan menjual ke pedagang selanjutnya ini dikarenakan prinsip kemitraan, dimana pedagang besar ini terkadang (walaupun tidak selalu) bisa memberikan pinjaman modal kepada pengumpul lokal untuk kemudian dipinjamkan kembali kepada pembudidaya yang kekurangan modal. Oleh karena hal ini, beberapa pembudidaya yang telah meminjam modal kepada pengumpul lokal harus mengembalikan pinjamannya dengan cara menjual hasil panennya ke pengumpul lokal tersebut. Saluran nilai rumput laut kering dari pembudidaya ke pengumpul lokal II:

Keseluruhan saluran tersebut menghasilkan pertambahan nilai sebesar Rp.2770,- per kg rumput laut kering dan jumlah biaya yang dihabiskan untuk menghasilkan pertambahan nilai dari pembudidaya ke pengumpul lokal adalah Rp. 4730,- per kg rumput laut kering. Hampir sama dengan jalur pemasaran melalui pengumpul lokal I, dalam saluran ini, dari jumlah pertambahan nilainya pembudidaya juga menerima bagian terbesar, yaitu $92,8 \%$ dari total pertambahan nilai dan menghabiskan bagian terbesar di sisi biaya (76,2\%). Dibandingkan dengan pemasaran ke pengumpul lokal I, pertambahan nilai yang dihasilkan melalui pemasaran rumput laut ini bernilai lebih sedikit. Hal ini dikarenakan saluran nilai yang berlangsung melalui pengumpul lokal II di Kabupaten Sumbawa ini juga lebih pendek dari saluran I karena proses pemasarannya langsung dilanjutkan ke pengumpul besar diluar daerah yaitu daerah Lombok.

\section{Pola Saluran 3}

Selain ke pedagang pengumpul, pembudidaya juga menjual rumput laut kering kepada home industry pengolahan rumput laut. Penjualan tersebut dilakukan di lokasi pembudidaya dengan melakukan klasifikasi kualitas rumput laut. Sebagian besar perusahaan industri makanan yang mengolah rumput laut di Kabupaten Sumbawa masih termasuk ke dalam kategori usaha kecil dan menengah (UKM) dan skala rumah tangga. Industri ini memasok kebutuhan bahan baku rumput laut mereka langsung dari para pembudidaya di desa terdekat. Dengan memasok langsung dari pembudidaya maka kualitas rumput laut bermutu yang dibutuhkan dapat diperoleh dengan lebih mudah. Oleh karena kebutuhan rumput laut yang dibutuhkan kualitasnya harus

1. Biaya Tetap $(11,7 \%)$

2. Biaya Operasional $(49,4 \%)$

3. Biaya Tenaga Kerja $(38,9 \%)$

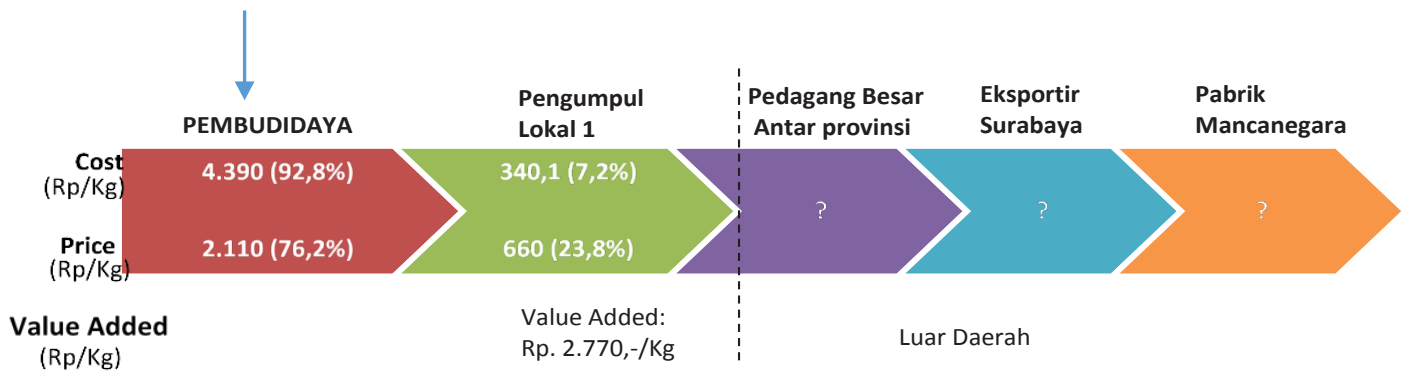

Gambar 2. Pola Saluran Pemasaran Rumput Laut 2 
bagus maka seringkali pembudidaya mematok harga yang lebih mahal dari harga standar. Disini pembudidaya bisa dengan bebas menentukan harga tanpa mengikuti harga pasaran dengan syarat adanya kesepakatan dengan pihak pembeli, yakni pengolah itu sendiri. Saluran pemasaran rumput laut kering dari pembudidaya keperusahaan pengolahan dodol rumput laut disajikan pada Gambar 3.

Dalam saluran nilai ini pertambahan nilai yang didapat dari home industry pengolahan dodol rumput laut yang ada di Kabupaten Sumbawa. Saluran untuk home industry makanan olahan ini menghasilkan pertambahan nilai yang lebih besar dibanding dengan saluran nilai lain, yakni sebesar Rp.45.000,- per kg rumput laut olahan, dengan jumlah biaya untuk menghasilkan pertambahan nilai sebesar Rp. 6191,- per kg. Dari jumlah pertambahan nilai tersebut, pengolah (prosessor) makanan olahan berbahan baku rumput laut, yakni pengolah dodol rumput laut mendapatkan bagian tertinggi dari pertambahan nilai yaitu sebesar $75,8 \%$ dari total pertambahan nilai dalam saluran.

Sedangkan dari segi biaya pembudidaya tetap menjadi pihak yang mengeluarkan biaya terbesar untuk usaha budidayanya, yakni sebesar $71 \%$. Di sisi lain, pengolah dapat melakukan efisiensi dimana dengan biaya yang lebih rendah dari pembudidaya, pengolah dapat menghasilkan keuntungan yang lebih besar. Setelah diproses oleh pengolah dodol rumput laut, hasil produksi kemudian dipasarkan melalui agen-agen dan minimarket lokal (Sumbawa) dan luar daerah yaitu Mataram, serta dikirim ke distributor di Surabaya.

\section{MARGIN DAN EFISIENSI SALURAN PEMASARAN}

Margin adalah suatu istilah yang digunakan untuk menyatakan perbedaan harga yang dibayar kepada penjual pertama dan harga yang dijual pada pembeli terakhir. Tabel 3 menunjukkan bahwa margin terbesar terdapat pada saluran pemasaran III, yakni sebesar Rp 35.000/Kg. Hal ini dikarenakan saluran pemasaran 3 adalah saluran pemasaran dalam bentuk produk olahan dan rantai pemasarannya pendek sehingga margin dan nilai tambah yang dihasilkan jauh lebih besar dibandingkan saluran 1 dan 2 . Sementara saluran pemasaran I dan II rumput laut yang dipasarkan dalam bentuk kering/raw material saja. Pada saluran pemasaran rumput laut dalam bentuk kering (raw material) terlihat margin dan keuntungan terbesar terdapat pada saluran pemasaran I. Margin pemasaran pada saluran I sebesar Rp.1.741,7 per kg dan keuntungan sebesar Rp. 3.526 per kg.

Untuk mengetahui efisiensi pemasaran rumput laut dapat dilihat dari margin dan bagian yang diterima pembudidaya (farmers share) pada setiap saluran pemasaran yang ada. Farmers share merupakan bagian yang diterima pembudidaya dengan harga yang diterima konsumen. Saluran pemasaran dikatakan paling efisien apabila memiliki margin terkecil dan farmers share terbesar (Roziah, 2005 dalam Sobirin 2009). Jika dilihat dari margin dan farmers share pada Tabel 3, saluran II memiliki nilai margin terkecil (Rp. 1000) dan farmers share terbesar ( $86,67 \%)$. Hal ini berarti bahwa saluran pemasaran II adalah saluran pemasaran yang paling efisien diantara 3 saluran pemasaran dapat dilihat pada Tabel 3 .

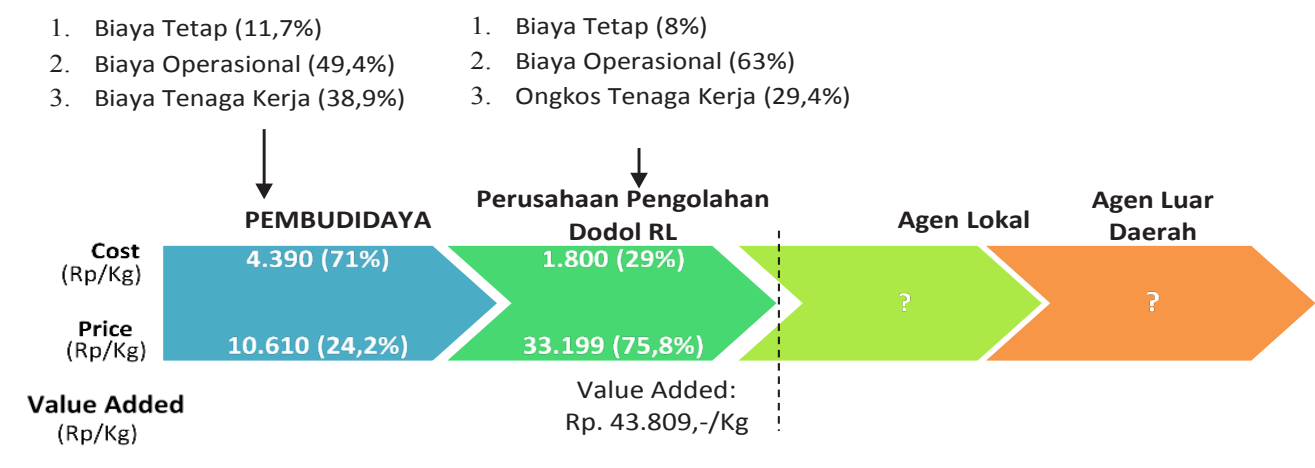

Gambar 2. Pola Saluran Pemasaran Rumput Laut 2 
Tabel 3. Total Biaya, Keuntungan dan Margin Pemasaran Rumput Laut Setiap Saluaran Pemasaran di Kabupaten Sumbawa, 2012

\begin{tabular}{lccc}
\hline \multirow{2}{*}{ Uraian } & \multicolumn{2}{c}{ Kering } & Produk Olahan \\
\cline { 2 - 4 } & Saluran Pemasaran 1 & Saluran Pemasaran 2 & Saluran Pemasaran 3 \\
\hline Margin pemasaran (Rp/kg) & $1.741,7$ & $1.000,0$ & $35.000,0$ \\
Margin Pemasaran/ (\%) & 19,9 & 13,3 & 70,0 \\
Kontribusi sektor pembudidaya (\%) & 80,1 & 86,67 & 30,00 \\
\hline
\end{tabular}

\section{PENUTUP}

Lembaga pemasaran yang terlibat dalam saluran pemasaran di kawasan sentra minapolitan adalah: pedagang pengumpul lokal 1 , pedagang pengumpul lokal 2 pedagang pengumpul besar, dan pengolah. Masingmasing lembaga memiliki fungsi pemasaran yang dilakukan perorangan atau kelompok. Ada tiga fungsi pemasaran dalam pemasaran rumput laut di Kabupaten Sumbawa yaitu: fungsi pertukaran, fungsi fisik, dan fungsi fasilitas. Permasalahannya adalah masih terdapat praktek-praktek lembaga pemasaran yang dapat mengurangi kualitas produk rumput laut. Pola saluran pemasaran rumput laut di Kabupaten Sumbawa terdiri dari tiga (3) saluran. Sifat produk yang disalurkan pada rantai 1 dan 2 sama yakni dalam bentuk raw material, sedangkan sifat produk pada saluran 3 sudah dalam bentuk olahan.

Saluran yang paling efisien diantara ke tiga saluran pemasaran adalah saluran pemasaran 2. Hal ini terlihat nilai margin pemasaran yang terkecil dan farmer's share yang terbesar. Margin pemasaran berhubungan negatif dengan bagian yang diterima pembudidaya (farmer share). Semakin tinggi margin pemasaran, maka semakin kecil farmer's share yang diterima pembudidaya. Pada saluran 3 keuntungan yang diperoleh pembudidaya juga besar, namun kesenjangan harga di pembudidaya dengan pengolah sangat besar dengan biaya yang tidak terlalu jauh selisihnya. Sehingga saluran 3 dikategorikan kurang efisien. Meskipun demikian, industri pengolahan dapat menghasilkan pertambahan nilai yang jauh lebih besar dibandingkan dengan pemasaran ke dalam bentuk raw material. Dengan banyaknya variasi diversifikasi produk olahan rumput laut, maka industri pengolahan rumput laut memiliki prospek untuk dikembangkan. Berdasarkan kondisi tersebut maka perlu dukungan kebijakan untuk menguatkan saluran pemasaran 2 dengan meningkatkan keberpihakan terhadap pembudidaya rumput laut.

\section{UCAPAN TERIMAKASIH}

Penulis mengucapkan terimakasih kepada Balai Besar Riset Sosial Ekonomi Kelautan dan Perikanan (BBRSEKP) yang telah memfasilitasi pelaksanaan kegiatan penelitian ini, rekanrekan peneliti yang survey lapang dalam rangka pengumpulan data terkait dengan penelitian ini. Selain itu, ucapan terima kasih juga kepada segenap tim redaksi yang telah memberikan masukan dan arahan untuk penyempurnaan tulisan ini

\section{DAFTAR PUSTAKA}

Asian Development Bank. 2006. Sustainable Aquaculture Development for Food Security and Poverty Reduction. Project Number 35183.

Anggadiredja, J.T. 2008. Rumput Laut: Pembudidayaan, Pengolahan, dan Pemasaran Komoditas Perikanan Potensial. Penebar Swadaya, Jakarta.

Dewi, U., 2006. Analisis Kelayakan Usahatani Dan Efisiensi Pemasaran Salak Pondoh (Kasus Di Kecamatan Madukara, Kabupaten Banjarnegara, Propinsi Jawa Tengah. Tesis, Institut Pertanian Bogor.

Direktorat Jenderal Pengolahan dan Pemasaran Hasil Perikanan. 2012. Konsep Pengembangan Industrialisasi Rumput Laut. Kementerian Kelautan dan Perikanan. Jakarta.

Harifuddin, Aisyah dan Budiman, 2011. Analisis Margin dan Efisiensi Pemasaran Rumput Laut di Desa Mandalle Kecamatan Mandalle, Kabupaten Pangkep. Jurnal AGRIBISNIS Vol. X (3). Hal 38-48. 
Hikmayani, Y., T. Apriliani, A. Zammroni, 2005. Analisis pemasaran rumput laut di Wilayah Potensial di Indonesia. Jurnal Kebijakan dan Riset Sosial Ekonomi Kelautan dan Perikanan. Balai Besar Riset Sosial Ekonomi Kelautan dan perikanan. Badan Riset Kelautan dan Perikanan. Jakarta. Hal 159-175.

Indriani, H dan Suminarsih E. 1999. Budidaya, Pengolahan, dan Pemasaran Rumput Laut. Tim Penulis PS. Cet. 6 - Jakarta. Penerbit Swadaya, Jakarta.

Juanda, B. 2009. Metodologi Penelitian Ekonomi dan Bisnis. Edisi 2. ISBN 978-979-493-158-5. IPB Press, Bogor. 202 hal.

Maholtra, N.K. 1996. Marketing Research: Analysis Applied Orientation. Second Edition, Prentice Hall International Inc., New Jersey.

Purcell. W.D. 1979. Agricultural Marketing: System, Coordination, Cash and Future Price. Prentice Hall Company, Virginia.

Roziah,S.,2005. Efficiency studies Pondoh Line Marketing (Salacca Adulis Reinw Pondoh cv) in sub district Turi Sleman. essay. UNSOED, Purwokerto. 102 p. (Unpublished)

Singarimbun, M. dan Effendi, 1995, Metode Penelitian Survei, Edisi II, Penerbit PT. Pustaka LP3ES Indonesia, Jakarta.

Sobirin, T. 2009. Efisiensi Pemasaran Pepaya (Carica papaya L.) di Kecamatan Subang Kabupaten Banyumas. Skripsi. Universitas Jenderal Soedirman. Purwokerto.

Soekartawi, D.R. 2002. Prinsip Dasar Manajemen Pemasaran Hasil-hasil Pertanian. PT. Raja Grafindo. Jakarta.

Tomek. W.G. and K.L. Robinson. 1990. Agricultural Product Price. $3^{\text {rd }}$ ed. New York, USA: Cornell University.

Triyanti, R., N. Shafitri. 2012. Kajian Pemasaran Ikan Lele (Clarias Sp) dalam mendukung industrialisasi Perikanan Budidaya. 